\title{
Bile duct stone caused by a fishbone
}

\section{Lu Lu, Wenyuan Song}

Department of Hepatobiliary and Pancreatic Surgery, The Second Affiliated Hospital of Hainan Medical University, Haikou, China Correspondence to: Lu Lu, M Med. Department of Hepatobiliary and Pancreatic Surgery, The Second Affiliated Hospital of Hainan Medical University, No. 48, Baishuitang Road, Haikou 570100, China. Email: lugegewu@163.com.

Submitted Jul 05, 2020. Accepted for publication Aug 10, 2020.

doi: 10.21037/hbsn-20-575

View this article at: http://dx.doi.org/10.21037/hbsn-20-575

Common bile duct stones caused by fishbone are rare. Opinions vary on how fish bone entered the bile duct. Here we report a case that an 80 -year-old male who had eaten fish several months ago and presented at the Emergency Room because of right upper abdominal pain. Computed tomography scan revealed a thin arc- shaped high-density shadow (Panel A). It is often difficult to show the shape of fishbone via Magnetic Resonance Cholangiopancreatography as it can only indicate the filling defect of bile duct (Panel B). Later, the patient underwent laparoscopic common bile duct exploration, and we found an arc-shaped fish bone in bile duct stones (Panel C,D).
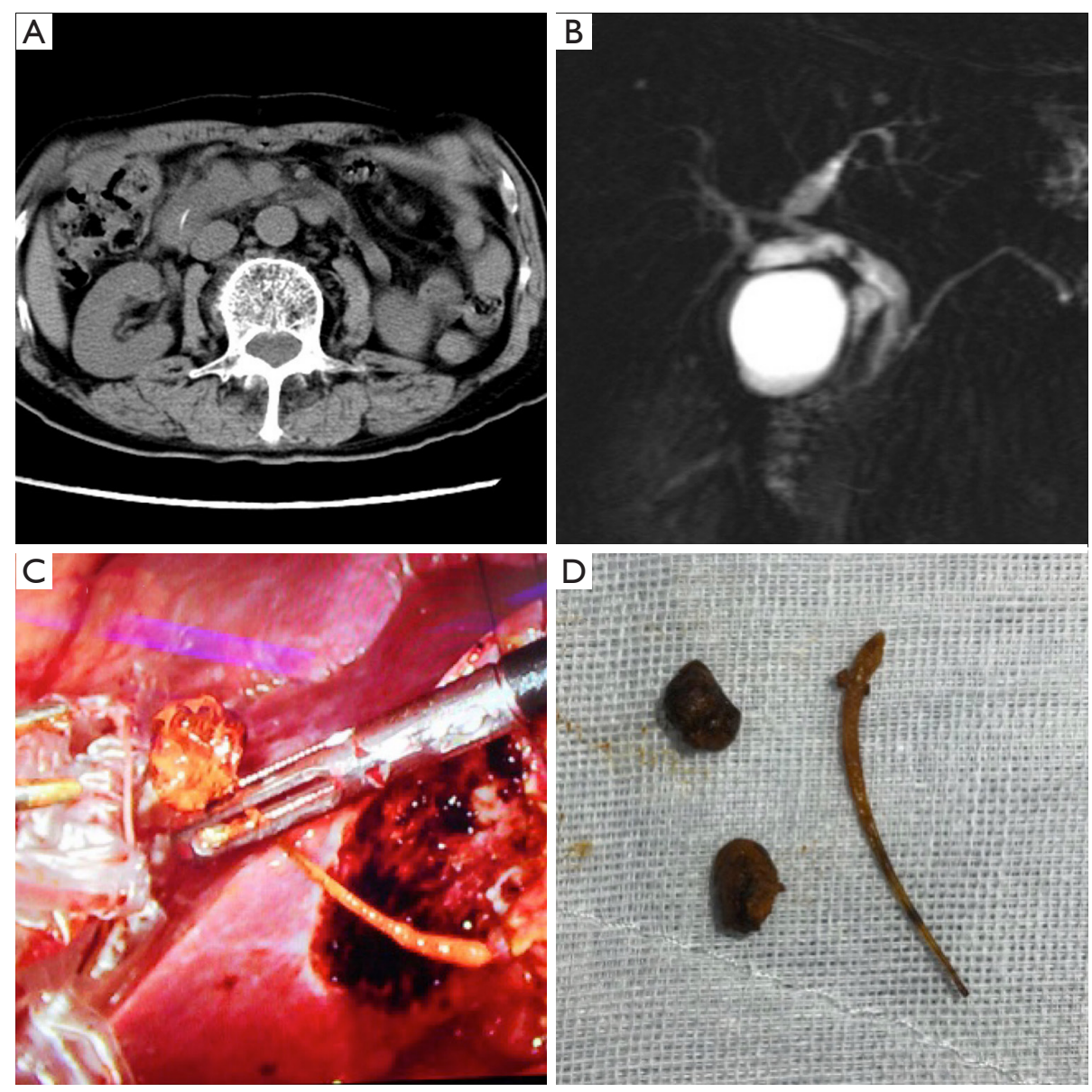


\section{Acknowledgments}

Funding: None.

\section{Footnote}

Provenance and Peer Review: This article was a standard submission to the Hepatobiliary Surgery and Nutrition. The article did not undergo external peer review.

Conflicts of Interest: Both authors have completed the ICMJE uniform disclosure form (available at https://hbsn. amegroups.com/article/view/10.21037/hbsn-20-575/coif). The authors have no conflicts of interest to declare.

Ethical Statement: The authors are accountable for all aspects of the work in ensuring that questions related to the accuracy or integrity of any part of the work are appropriately investigated and resolved. Written informed consent was obtained from the patient for publication of this manuscript and any accompanying images.

Open Access Statement: This is an Open Access article distributed in accordance with the Creative Commons Attribution-NonCommercial-NoDerivs 4.0 International License (CC BY-NC-ND 4.0), which permits the noncommercial replication and distribution of the article with the strict proviso that no changes or edits are made and the original work is properly cited (including links to both the formal publication through the relevant DOI and the license). See: https://creativecommons.org/licenses/by-nc-nd/4.0/.

Cite this article as: $\mathrm{Lu} \mathrm{L}$, Song W. Bile duct stone caused by a fishbone. HepatoBiliary Surg Nutr 2021;10(2):295-296. doi: 10.21037/hbsn-20-575 